О. С. Ткаченко, В. М. Коваленко, Г. М. Шаяхметова, I. С. Блажчук, I. I. Тубальцева

\title{
Ефективність сумісного застосування метформіну та ліпофлавону за умов метаболічного синдрому в щурів
}

\author{
Державна установа «Інститут фармакології та токсикології \\ Національної академії медичних наук України», м. Київ
}

Ключові слова: метаболічний синдром, щури, гонади, метформін, ліпофлавон

Встановлено, що в чоловіків молодого та середнього віку, які страждають на метаболічний синдром (MC) та ожиріння, досить поширеними $€$ випадки порушень статевої функції, що становить важливі медичну, демографічну та соціальну проблеми [1, 2]. Незважаючи на те, що поєднання дотримання дієти та підвищення фізичної активності повинно бути основою для лікування МС та ожиріння, на практиці використання лише не медикаментозних методів корекції маси тіла часто $\epsilon$ неефективним i короткотривалим. Це спонукає деяких пацієнтів вдаватись до фармакотерапії. Враховуючи зростаючу кількість осіб молодого віку з МС, спостерігається збільшення застосування метформіну, який зазвичай призначається за даних умов $[3,4]$. Сучасні дані щодо ефективності застосування метформіну за порушень чоловічої репродуктивної функції є суперечливими $[5,6]$. Отже, пошук нових мішеней для терапії патологій, пов'язаних 3 MC, $€$ одним 3 найважливіших завдань сучасної фундаментальної та прикладної медицини. Такими мішенями можуть бути, зокрема, біологічні процеси, що відіграють ключову патогенетичну роль у розвитку тих чи інших небажаних змін в організмі. Очевидно, що широта спектра нозологічних форм, які підлягають таргетній корекції, залежить від універсальності патогенетичних чинників. Одним 3 таких патогенетичних про-

(с) Колектив авторів, 2019 цесів є окиснювальний стрес, який певною мірою притаманний переважній більшості патологічних станів і, як відомо, відіграє важливу роль як у патогенезі МC, так і в розвитку порушень чоловічої репродуктивної функції [7-9]. Саме тому ідея використання разом з метформіном ліпосомальної форми кверцетину (ліпофлавону) як препарату, що має потужні антиоксидантні властивості $[10,11]$, видалась нам логічною в аспекті зниження стресогенного впливу МС на чоловічі гонади. Тим більше, що іншими авторами раніше показано позитивні ефекти ліпофлавону за умов введення на фоні експериментального цукрового діабету $[12,13]$.

Мета дослідження - оцінити ефективність метформіну та його комбінації з ліпофлавоном за введення щурам-самцям з МС за основними критеріальними показниками гонадопротекторної дії.

Матеріали та методи. План дослідження був розглянутий i схвалений Комітетом 3 біоетики ДУ «Інститут фармакології та токсикології НАМН України»; усі процедури, пов'язані 3 гуманним поводженням із тваринами та використанням їх у експериментах, були дотримані.

Для відтворення моделі МС у експериментах було використано фруктозу кристалічну харчову (виробник Туреччина, постачальник - Голландія, серія LS2P00251506-247). У дослідженні використовували самців щурят з початковою масою тіла 50-70 г, віком 3 тижні. Крім того, для парування 3 самцями використовували віргільних статевозрілих самиць масою тіла 160180 г. Тварини надані розплідником 
експериментально-біологічної клініки ДУ «Інститут фармакології та токсикології НАМН України». Щурів утримували в стандартних умовах віварію за температури $22-24{ }^{\circ} \mathrm{C}$ і відносної вологості 30-70 \%, з вільним доступом до корму та води. Тварин було розподілено методом рандомізації на 4 групи по 12 щурят у кожній: 1 група - контроль: тварини, що отримували питну воду; 2 група - тварини, які замість питної води отримували $10 \%$ розчин фруктози протягом 60 днів (модель МС) [14]; 3 група - тварини 3 $\mathrm{MC}$, яким внутрішньошлунково зондом уводили метформін у дозі 266 мг/кг маси тіла в $1 \%$ крохмальному гелі протягом останніх 30 днів споживання фруктози; 4 група - сумісне введення на фоні MC метформіну в зазначеному вище режимі та ліпофлавону внутрішньоочеревинно у вигляді суспензії в дозі 3,1 мг/кг м. т. (за кверцетином) у фізіологічному розчині протягом останніх 30 днів споживання фруктози. Для введення тваринам використовували метформін виробництва ЛЕК С.А., Польща, серіï DN0372 та ліпофлавон виробництва ТОВ «Наномедтех», Україна, дослідна серія 050715 [15].

Досліджувані препарати вводили тваринам у дозовому режимі, що застосовується в клініці (відповідно до інструкцій) з урахуванням коефіцієнта видової чутливості [16].

Через 42 дні від початку експерименту щурів парували з інтактними самицями у співвідношенні самець : самиця $1: 1$ протягом 3 естральних циклів для визначення фертильності. Після закінчення терміну парування самців щурів піддавали евтаназії шляхом декапітації під анестезією парами діетилового ефіру. Для дослідження брали сім'яники та епідидиміси. Кількість сперматозоїдів вивчали, використовуючи суспензію клітин придатка сім'яника, яку готували 3 дотриманням стандартних методичних вимог [17].

Вплив МC i досліджуваних лікарських засобів на фертильність самців щурів визначали за формулою:

$$
\frac{\text { число запліднених самиць }}{\text { число вагітних самиць }} 100 \% \text { • }
$$

Рівень загального тестостерону в сироватці крові визначали, використовуючи набір Testosterone ELISA виробництва DRG Instruments GmbH (Німеччина), методом твердофазного імуноферментного аналізу згідно з інструкцією виробника. Вимірювання оптичної щільності калібраторів і зразків проводили на мікропланшетному ридері BioTek (CШA).

У гомогенаті сім'яників визначали швидкість аскорбат-залежного утворення продуктів реакції з тіобарбітуровою кислотою (ТБК) [18], активність СОД [19], вміст відновленого глутатіону [20]. У сироватці визначали рівень церулоплазміну методом Равіна [21]. Отримані дані представляли як середне значення \pm похибка середнього (M \pm $\mathrm{m})$. Статистичний аналіз результатів експерименту проводили з використанням однофакторного дисперсійного аналізу (ANOVA). Різницю між досліджуваними показниками вважали статистично вірогідною в разі значення $\mathrm{p} \leq$ 0,05 [22].

Результати та їх обговорення. Результати морфометричного дослідження гонад щурів, у яких МС розвинувся в ювенільному віці, за умов застосування метформіну в комбінації з ліпофлавоном наведено в таблиці 1. Виявлені нами зміни абсолютної маси та об'єму сім'яників щурів, які, починаючи від закінчення підсосного періоду, споживали високофруктозну дієту, віддзеркалюють дегенеративні зміни в сім'яних канальцях [23]. Варто відзначити, що в попередній серії експериментів ми показали відсутність впливу як метформіну, так і ліпофлавону на даний інтегральний показник стану гонад. Застосування метформіну та ліпофлавону за аналогічних доз і тривалості застосування в режимі сумісного введення сприяло нормалізації маси та об'ємів гонад до показників контрольного рівня (табл. 1).

Стосовно маси придатків сім'яників, то в попередньому експерименті монотерапія метформіном і ліпофлавоном не справила позитивного впливу, тоді як за їхнього сумісного введення даний показник залишився практично на рівні контролю (табл. 1). 
Морфометричні показники стану гонад щурів самиів з метаболічним синдромом, що розвинувся в ювенільному віці, та за умов сумісного введення метфорліну (внутрішньошлунково, $266 \mathrm{mг/к2)} \mathrm{з} \mathrm{ліпофлавоном}$ (внутрішньоочеревинно, 3,1 мг/кг) $(M \pm m, n=12)$

\begin{tabular}{|l|c|c|c|c|}
\hline \multirow{2}{*}{ Показник } & \multicolumn{4}{|c|}{ Експериментальна група } \\
\cline { 2 - 5 } & контроль & $\begin{array}{c}\text { метаболічний } \\
\text { синдром }\end{array}$ & $\begin{array}{c}\text { метаболічний } \\
\text { синдром + } \\
\text { метформін }\end{array}$ & $\begin{array}{c}\text { метаболічний } \\
\text { синдром + метфор- } \\
\text { мін+ ліпофлавон }\end{array}$ \\
\hline $\begin{array}{l}\text { Маса } \\
\text { сім'яників, г }\end{array}$ & $3,56 \pm 0,12$ & $3,10 \pm 0,06^{\star}$ & $3,25 \pm 0,05^{\star}$ & $3,48 \pm 0,08^{\#, \diamond}$ \\
\hline $\begin{array}{l}\text { Об'єм } \\
\text { сім'яників, см }\end{array}$ & $3,24 \pm 0,14$ & $2,78 \pm 0,10^{\star}$ & $2,84 \pm 0,08^{*}$ & $3,17 \pm 0,05^{\#, \diamond}$ \\
\hline $\begin{array}{l}\text { Маса епідиди- } \\
\text { місів, г }\end{array}$ & $0,89 \pm 0,02$ & $0,81 \pm 0,02^{*}$ & $0,81 \pm 0,01^{*}$ & $0,88 \pm 0,02^{\#, 0}$ \\
\hline
\end{tabular}

Примітка. * $p \leq 0,05$ порівняно з контрольною групою, ${ }^{*} p \leq 0,05$ порівняно з групою МС, ${ }^{\circ} p \leq 0,05$ порівняно 3 групою «Метфорлін».

Важливим для оцінки стану репродуктивної системи є показник нормоспермії. Дані, наведені на рисунку 1, свідчать, що комбіноване введення досліджуваних препаратів щурам, на додаток до нормалізуючої дії на морфометричні показники гонад, також сприяло й відновленню кількості сперматозоїдів з хвостової частини епідидимica.

Збільшення кількості сперматозоїдів сприяло зростанню індексу фертильності щурів-самців, які отримували комбіновану терапію (рис. 2).

Для отримання даних стосовно впливу екзогенних та ендогенних факторів корисним $€$ застосування тесту домінантних леталей, в якому самиць піддають евтаназії в середині третього триместру вагітності. У даному тесті визначають до- та післяімплантаційну загибель. Рівень ембріофетальної смертності в самиць, запліднених самцями, які мають патологію репродуктивної системи, є одним з інтегральних показників, що характеризують генеративну функцію. Порівнюючи результати дослідження рівня ембріональної смертності в самиць, що були запліднені піддослідними самцями (для обрахунку були використані, у тому числі й дані щодо тварин контрольної групи та з МC із попередньої серії експерименту), можна відзначити зростання відсотка до- та післяімплантаційної, а також загальної смертності в групі з МС порівняно 3 контролем у 1,$9 ; 3$ і майже 2 рази відповідно (рис. 3). Звертає на себе увагу, що введення метформіну не позначилося суттєво на показниках загальної ембріональної летальності порівняно 3 групою з MC, у той час як у групі тварин, що отримували комбіновану терапію метформіном i ліпофлавоном,

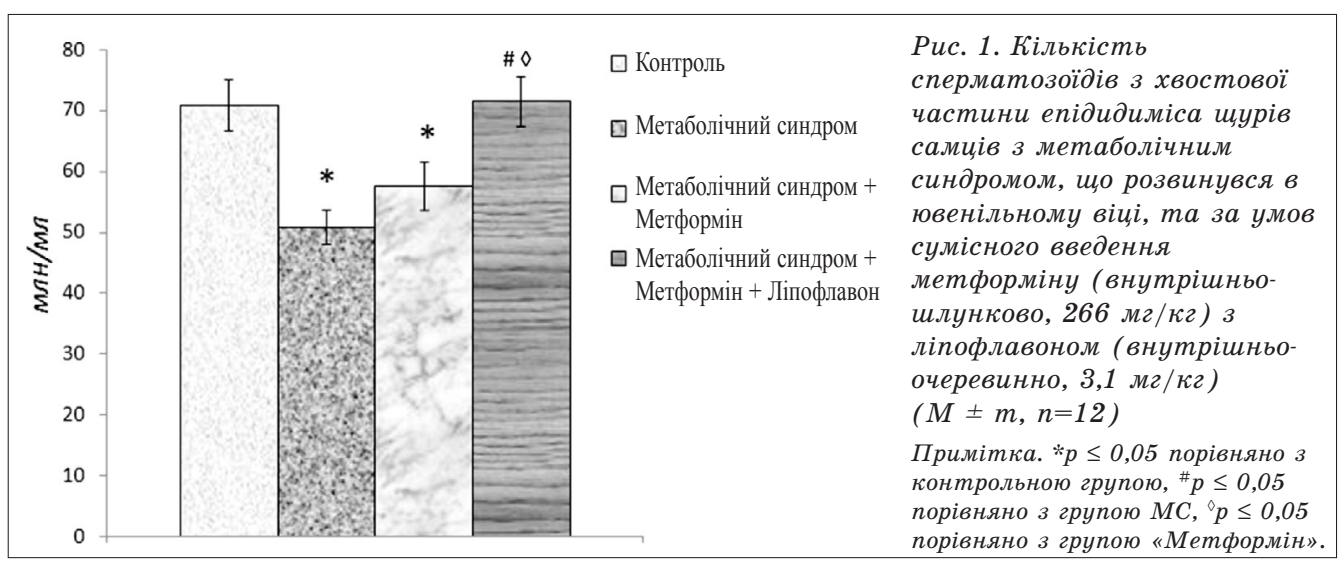




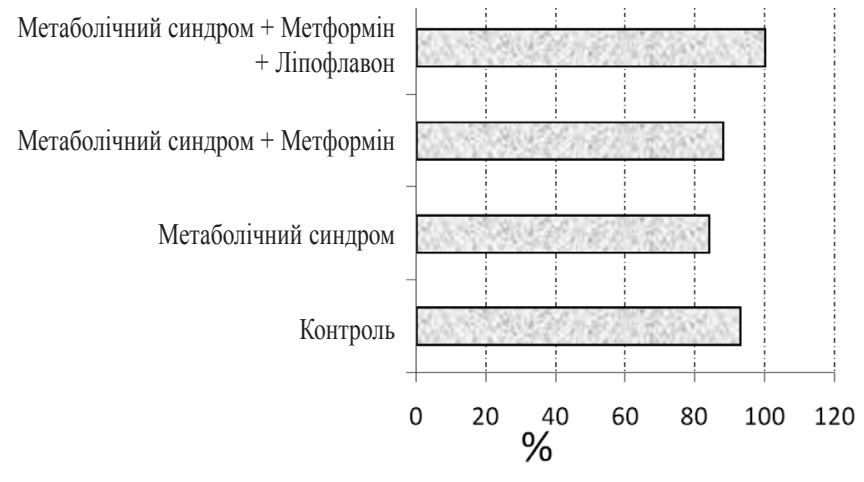

Метаболічний синдром + Метформін

+ Ліпофлавон

Метаболічний синдром + Метформін

Метаболічний синдром

Контроль
Рис. 2. Індекс фертильності щурів-самиів з метаболічним синдролол, що розвинувся в ювенільному віці, та за умов сумісного введення метформіну (внутрішньошлунково, 266 мг/кг) з ліпофлавоном (внутрішньоочеревинно, 3,1 мг/кг) $(M \pm m, n=12$ ) загальний відсоток ембріональних втрат був нижчим у 2,3 разу порівняно з групою з МС.

Таким чином, за результатами морфометрії гонад, кількістю сперматозоїдів 3 хвостової частини епідидимісів, індексом фертильності та показниками ембріолетальності сумісне введення метформіну та ліпофлавону виявилось більш ефективним для корекції наслідків МC на репродуктивну функцію, ніж окреме застосування базового препарату метформіну.

Незважаючи на низьке кисневе навантаження, що характеризує тестикулярне мікросередовище, ця тканина залишається вразливою до окиснювального стресу завдяки великій кількості високоненасичених жирних кислот, а також наявності систем, що потенційно можуть генерувати АФК: окиснювально-відновні ферменти, у тому числі ксантин, НАДФН-оксидази, цитохром Р-450 [24-26]. Дані дослідження стану про/антиоксидантної системи сім'яників щурів з МC та за введення метформіну i ліпофлавону наведено в таблиці 2.

Показано, що за MC у сім'яниках щурів зростала швидкість індукованого аскорбатом утворення ТБК-реактантів, компенсаторно підвищувалась активність СОД майже на 40 \% і 14 \% відповідно, достовірно зменшувався вміст відновленого глутатіону. Зростання рівня ПОЛ призводить до структурнофункціональних порушень у клітинах сім'яників, а зменшення вмісту відновленого глутатіону може бути пов'язане зі збільшенням його використання $\mathrm{GSH}$ для детоксикації надлишку вільних радикалів, що утворюються внаслідок активації ПОЛ [27]. Крім того, у сироватці крові за даних умов у 1,2 разу порівняно 3 контролем знижувався вміст церулоплазміну - основного позаклітинного антиоксиданта крові, здатного на 50 \% інгібувати ПОЛ за рахунок перехвату та інактивації супероксидного радикала [28]. Наші дані

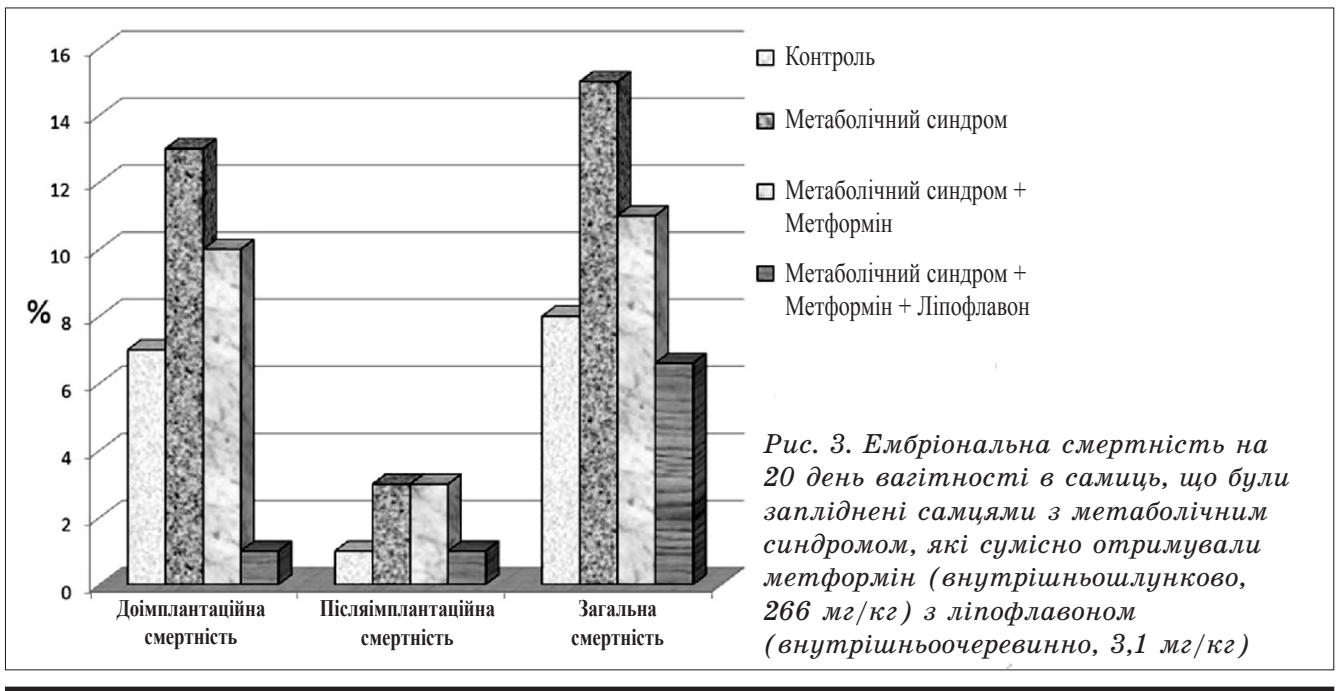


Показники про/антиоксидантної системи сім'яників $і$ сироватки крові шурів 3 метаболічнил синдролол, що розвинувся в ювенільнолу віці, та за сулісного введення метфорліну (внутрішньошлунково, 266 мг/кг) з ліпофлавонол (внутрішньоочеревинно, $3,1 \mathrm{мг} / \kappa 2)(M \pm m, n=12)$

\begin{tabular}{|l|c|c|c|c|}
\hline \multirow{2}{*}{ Показник } & \multicolumn{4}{|c|}{ Експериментальна група } \\
\cline { 2 - 5 } & контроль & $\begin{array}{c}\text { метаболіч- } \\
\text { ний син- } \\
\text { дром }\end{array}$ & $\begin{array}{c}\text { метаболічний } \\
\text { синдром }+ \\
\text { метформін }\end{array}$ & $\begin{array}{c}\text { метаболічний синд- } \\
\text { ром + метформін+ } \\
\text { ліпофлавон }\end{array}$ \\
\hline $\begin{array}{l}\text { Швидкість утво- } \\
\text { рення ТБК- } \\
\text { реактантів у сім'я- } \\
\text { никах, нмоль/хв } \\
\text { мг білка }\end{array}$ & $38,1 \pm 5,5$ & $51,7 \pm 2,6^{*}$ & $43,1 \pm 5,5$ & $33,2 \pm 5,7^{\#}$ \\
\hline $\begin{array}{l}\text { Активність СОД у } \\
\text { сім'яниках, у. о./ } \\
\text { мг білка }\end{array}$ & $6,47 \pm 0,68$ & $8,92 \pm 0,79^{\star}$ & $6,68 \pm 0,83$ & $6,66 \pm 0,55^{\#}$ \\
\hline $\begin{array}{l}\text { Вміст відновлено- } \\
\text { го глутатіону в } \\
\text { сім'яниках, } \\
\text { нмоль/мг білка }\end{array}$ & $3,92 \pm 0,13$ & $3,36 \pm 0,08^{*}$ & $3,71 \pm 0,18$ & $3,550 \pm 0,095^{\#}$ \\
\hline $\begin{array}{l}\text { Вміст церуло- } \\
\text { плазміну в сиро- } \\
\text { ватці крові, мг/л }\end{array}$ & $433,68 \pm$ \\
\hline
\end{tabular}

Примітка. * $p \leq 0,05$ порівняно з контрольною групою, ${ }^{*} p \leq 0,05$ порівняно з групою $\mathrm{MC.}$

стосовно рівня церулоплазміну співпадають з результатами клінічних досліджень, де було показано статистично достовірне зниження вмісту церулоплазміну сироватки за МС і цукрового діабету [29]. Якщо введення щурам метформіну в монорежимі не справило суттєвого позитивного впливу на показники, що характеризують стан про/антиоксидантної рівноваги в сім'яниках і в організмі в цілому (табл. 2), то сумісне його застосування 3 ліпофлавоном, коригуючи рівень активності СОД і вміст відновленого глутатіону, дозволило знизити активність процесів ПОЛ на 36 \% порівняно з групою МС. Крім того, рівень церулоплазміну сироватки крові за цих умов зростав на $60 \%$, що свідчить про мобілізацію компенсаторних можливостей організму, спрямованих на відновлення рівноваги між антиоксидантами та прооксидантами.

У тварин з МС спостерігався спад стероїдогенної активності сім'яників (зниження вмісту тестостерону в сироватці крові в 1,6 разу порівняно з контролем), що може бути розцінено як один з ком- понентів загального зриву адаптації, пов'язаного з наявністю MC (рис. 4).

Окреме введення метформіну не справляло позитивного впливу на гормональний фон щурів-самців (рис. 4). Водночас його застосування сумісно 3 ліпофлавоном сприяло відновленню рівня тестостерону до контрольних значень.

Незважаючи на загалом суперечливі дані стосовно впливу метформіну на чоловічу репродуктивну систему, є повідомлення, що даний препарат може змінювати функцію сім'яників безпосередньо за участю AMPK (АМФ-активована протеїнкіназа)-залежних та незалежних механізмів, і його ефекти включають поліпшення функції сперматозоїдів й імовірність запліднення [30]. Результати нашого дослідження свідчать на користь того, що застосування лише одного метформіну $€$ недостатнім для корекції порушень репродуктивної здатності, викликаних МС. Доцільним є використання речовин із ширшим спектром терапевтичної активності, як, наприклад, використаний нами в дослідженні ліпофлавон, який являє собою фосфатидилхолінові ліпосоми з кверцетином - 


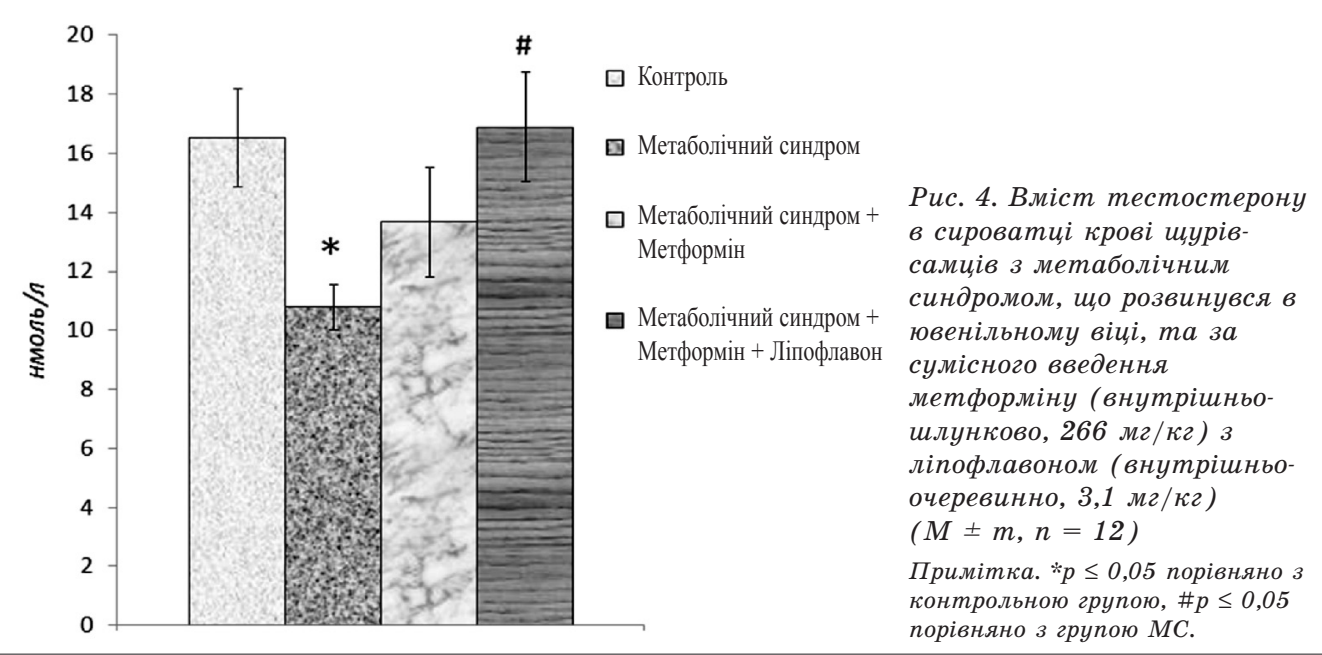

біофлавоноїдом з потужними антиоксидантними та протизапальними властивостями $[10,11]$. Перевагою застосування ліпосомальної форми кверцетину за даних умов є висока біодоступність препарату та наявність мембранопротекторної дії за рахунок комплексного впливу «препарат-партнер - ліпосоми» [31].

\section{Висновки}

1. За показниками морфометрії гонад, нормоспермії, фертильності та рівня ембріональної смертності комбінована терапія метформіном і ліпофлавоном порушень репродуктивної функ-

ції щурів-самців з МС є більш ефективною, ніж введення метформіну в монорежимі.

2. Введення до схеми лікування МC метформіном ліпофлавону сприяє оптимізації гонадопротекторної дії за рахунок відновлення про/антиоксидантного статусу тестикулярного середовища, про що свідчить позитивна модуляція активності компонентів антиоксидантного захисту (активність СОД, вміст церулоплазміну та відновленого глутатіону), зниження рівня ПОЛ і відновлення стероїдогенної активності сім'яників.

1. Kasturi S. S., Tannir J., Brannigan R. E. The metabolic syndrome and male infertility. Journal of andrology. 2008. V. 29 (3). P. 251-259.

2. Gonadal function in young adult males with metabolic syndrome. B. K. Choudhury, S. D. Choudhury, U. K. Saikia, D. Sarma. Diabetes \& Metabolic Syndrome: Clinical Research \& Reviews. 2013. V. 7 (3). P. 129-132.

3. Saklayen M. G. The global epidemic of the metabolic syndrome. Current hypertension reports. 2018. V. 20 (2). P. 12.

4. Novel therapeutic targets of metformin: metabolic syndrome and cardiovascular disease. R. Ladeiras-Lopes, R. Fontes-Carvalho, N. Bettencourt et al. Expert opinion on therapeutic targets. 2015. V. 19 (7). P. 869-877.

5. Effects of short term metformin administration on androgens in diabetic men. N. S. Shegem, A. M. A. Nasir, A. M. Batieha et al. Saudi medical journal. 2004. V. 25 (1). P. 75-78.

6. The effects of metformin and diet on plasma testosterone and leptin levels in obese men. M. Ozata, C. Oktenli, N. Bingol, I. C. Ozdemir. Obesity research. 2001. V. 9 (11). P. 662-667.

7. Oxidative stress, aging, and diseases. I. Liguori, G. Russo, F. Curcio et al. Clinical interventions in aging. 2018. V. 13. P. 757.

8. The impact of oxidative stress on testicular function and the role of antioxidants in improving it: a review. N. Asadi, M. Bahmani, A. Kheradmand, M. Rafieian-Kopaei Journal of clinical and diagnostic research: JCDR. 2017. V. 11 (5). IE01.

9. Yara S., Lavoie J. C., Levy E. Oxidative stress and DNA methylation regulation in the metabolic syndrome. Epigenomics. 2015. V. 7 (2). P. 283-300.

10. Antioxidant and anti-inflammatory activities of quercetin and its derivatives. M. Lesjak, I. Beara, N. Simin et al. Journal of Functional Foods. 2018. V. 40. P. 68-75.

11. Вплив ліпосомального кверцетину-ліпофлавону та ліпіну на процеси пероксидації ліпідів та білків при експериментальній гострій нирковій недостатності за умов одноразового введення. О. М. Горошко, Н. Я. Музика, А. О. Паламар та ін. Молодий вчений. 2014. № 12 (12), 238-240. 
12. Клименко К. І., Зеленський Д. С., Соловйов А. І. Вплив тривалого введення Ліпофлавону ${ }^{\circledR}$ на рівень глюкози в крові та судинну дисфункцію у щурів із експериментальним діабетом. Проблеми ендокринної патології. 2013. № 4. С. 39-46.

13. Comparative Study of the Effect of Various Forms of Quercetin on Experimental Diabetes. K. Posokhova, I. Stechyshyn, I. Krynytska et al. Romanian Journal of Diabetes Nutrition and Metabolic Diseases. 2018. V. 25 (4). P. 383-388.

14. (-)-Epicatechin mitigates high-fructose-associated insulin resistance by modulating redox signaling and endoplasmic reticulum stress. A. Bettaieb, M. A. V. Prieto, C. R. Lanzi et al. Free Radical Biology and Medicine. 2014. V. 72. P. 247-256.

15. Григор'єва Г. С., Краснопольський Ю. М., Конахович Н. Ф., Пасєчнікова Н. В. 2016. Патент України на винахід № 111762 «Спосіб отримання фармакологічно активного ліпосомального засобу, що містить кверцетин», заявка № а2014077695 від 08.07.2104, Бюл. № 11.

16. Guidance for Industry and Reviewers Estimating the Safe Starting Dose in Clinical Trials for Therapeutics in Adult Healthy Volunteers US of Department of Health and Human Services, FDA, CDER and CBER. URL: http://www.fda.gov/cder/guidance/index.htm.

17. Chitra K. C., Rao K. R., Mathur P. P. Effect of bisphenol A and co-administration of bisphenol A and vitamin $\mathrm{C}$ on epididymis of adult rats: a histological and biochemical study. Asian Journal of Andrology. 2003. V. 5 (3). Р. 203-208.

18. Стальная И. Д., Гаришвили Т. Г. Метод определения малонового диальдегида с помощью тиобарбитуровой кислоты. Современные методы в биохимии. Москва : Медицина, 1977. С. $66-68$.

19. Сирота Т. В. Новый подход в исследовании процесса аутоокисления адреналина и использование его для измерения активности супероксиддисмутазы. Вопросы медицинской химии. 1999. Т. 45 (3). С. 263-272.

20. Sedlak J., Lindsay R. H. Estimation of total, protein-bound, and nonprotein sulfhydryl groups in tissue with Ellman's reagent. Analytical Biochemistry. 1968. V. 25. P. 192-205.

21. Ravin H. A. Rapid test for hepatolenticular degeneration. The lancet. 1956. V. 267 (6925). P. $726-727$.

22. Glantz S. A. Primer of biostatistics. New Jork: Mc Graw-Hill Medical, 2005. 500 p.

23. Creasy D. M. Pathogenesis of male reproductive toxicity. Toxicol Pathol. 2001. V. 29. P. 64-76.

24. $\mathrm{A} \mathrm{Ca}^{2+}$-activated NADPH oxidase in testis, spleen, and lymph nodes. B. Bánfi, G. Molnár, A. Maturana et al. Journal of Biological chemistry. 2001. V. 276 (40), P. 37594-37601.

25. Xanthine oxidase inhibitors suppress testicular germ cell apoptosis induced by experimental cryptorchidism. A. Kumagai, H. Kodama, J. Kumagai et al. Molecular human reproduction. 2002. V. 8 (2). P. 118-123.

26. Zangar R. C., Davydov D. R., Verma S. Mechanisms that regulate production of reactive oxygen species by cytochrome P450. Toxicology and applied pharmacology. 2004. V. 199 (3). P. 316-331.

27. Glutathione metabolism and its implications for health. G. Wu, Y. Z. Fang, S. Yang et al. The Journal of nutrition. 2004. V. 134 (3). P. 489-492.

28. Обоснование применения церулоплазмина у пациентов с бронхиальной астмой. В. М. Провоторов, Ю. И. Филатова, Л. Н. Цветикова, М. В. Багмутова. Молодой ученый. 2016. № 1. C. $86-89$.

29. Jeppu A. K., Kumar K. A., Augusthy A. Plasma glucose and serum ceruloplasmin in metabolic syndrome and diabetes mellitus type 2. Recent Adv Biol Med. 2016. V. 2. P. 651.

30. Metforminin Reproductive Biology. M. Faure, M. J. Bertoldo, R. Khoueiry et al. Front Endocrinol (Lausanne). 2018. V. 22 (9). P. 675.

31. Реальная нанофармакология: 25 лет разработки и применения липосомальных лекарственных препаратов в Украине. А. С. Григорьева, А. Г. Кацай, Н. Ф. Конахович и др. Фармаком. 2016. № 1. C. 41-46.

\section{О. Є. Ткаченко, В. М. Коваленко, Г. М. Шаяхметова, I. С. Блажчук, І. І. Тубальцева Ефективність сумісного застосування метформіну та ліпофлавону за умов метаболічного синдрому в щурів}

У чоловіків молодого та середнього віку, які страждають на метаболічний синдром (МС) та ожиріння, досить поширеними є випадки порушень статевої функції. Сучасні дані щодо ефективності застосування метформіну за порушень чоловічої репродуктивної функції є досить суперечливими. Таким чином, пошук нових мішеней для таргетної терапії патологій, пов'язаних з МС, є одним з найважливіших завдань сучасної фундаментальної та прикладної медицини.

Мета дослідження - оцінка ефективності метформіну та його комбінації з ліпофлавоном за введення щурам-самцям з МС за основними критеріальними показниками гонадопротекторної дії.

У дослідах використовували самців щурят з початковою масою тіла 50-70 г, віком 3 тижні. Тварин було розподілено на 4 групи по 12 у кожній: 1- інтактні; 2 - тварини, які замість питної води отримували 10 \% розчин фруктози протягом 60 днів (модель МС); 3 - тварини з МС, яким внутрішньошлунково вводили метформін у дозі 266 мг/кг протягом останніх 30 днів споживання фруктози; 
4 - сумісне введення на фоні МС метформіну та ліпофлавону (внутрішньоочеревинно) у дозі 3,1 мг/кг м. т. (за кверцетином) протягом останніх 30 днів споживання фруктози.

Показано, що введення ліпофлавону до схеми лікування МС метформіном сприяло оптимізації гонадопротекторної дії за рахунок відновлення про/антиоксидантного статусу тестикулярного середовища, про що свідчить позитивна модуляція активності компонентів антиоксидантного захисту (активність СОД, вміст церулоплазміну та вміст відновленого глутатіону), зниження рівня пОЛ і відновлення стероїдогенної активності сім'яників.

Отримані результати свідчать на користь того, що сумісне введення метформіну та ліпофлавону виявилось більш ефективним для корекції наслідків МС на репродуктивну функцію, ніж окреме застосування базового препарату метформіну.

Ключові слова: метаболічний синдром, метформін, ліпофлавон, сім'яники

\section{А. Е. Ткаченко, В. Н. Коваленко, А. М. Шаяхметова, И. С. Блажчук, И. И. Тубальцева Эффективность совместного применения метформина и липофлавона при метаболическом синдроме у крыс}

У мужчин молодого и среднего возраста, страдающих метаболическим синдромом (МС) и ожирением, достаточно распространены случаи нарушений половой функции. Современные данные об эффективности применения метформина при нарушенях мужской репродуктивной функции достаточно противоречивы. Таким образом, поиск новых мишеней для таргетной терапии патологий, связанных с МС, является одной из важнейших задач современной фундаментальной и прикладной медицины.

Цель исследования - оценка эффективности метформина и его комбинации с липофлавоном при введении крысам самцам с МС по основным критериальным показателям гонадопротекторного действия.

В опытах использовали самцов крысят с начальной массой тела 50-70 г трехнедельного возраста. Животные были распределены на 4 группы по 12 в каждой: 1 - интактные; 2 - животные, которые вместо питьевой воды получали $10 \%$ раствор фруктозы в течение 60 дней (модель МС); 3 группа - животные с МС, которым внутрижелудочно вводили метформин в дозе 266 мг/кг в течение последних 30 дней потребления фруктозы; 4 - совместное введение на фоне МС метформина и липофлавона (внутрибрюшинно) в дозе 3,1 мг/кг м. т. (по кверцетину) в течение последних 30 дней потребления фруктозы. Показано, что введение липофлавона в схему лечения МС метформином способствовало оптимизации гонадопротекторного действия за счет восстановления про/ антиоксидантного статуса тестикулярного микроокружения, о чем свидетельствует положительная модуляция активности компонентов антиоксидантной защиты (активность СОД, содержание церулоплазмина и восстановленного глутатиона), снижение уровня ПОЛ и восстановление стероидогенной активности семенников. Совместное введение метформина и липофлавона оказалось более эффективным для коррекции последствий МС на репродуктивную функцию, чем отдельное применение базового препарата метформина.

Ключевые слова: метаболический синдром, метформин, липофлавон, семенники

\section{O. Ye. Tkachenko, V. M. Kovalenko, G. M. Shayakhmetova, I. S. Blazhchuk, I. I. Tubaltseva \\ Efficiency of metformin and lipoflavone co-administration in rats with metabolic syndrome}

It has been established that cases of sexual dysfunction are quite common in young and middle-aged men suffering from metabolic syndrome (MS) and obesity, which is an important medical, demographic and social problem. Taking into consideration the growing number of young people with MS, there is an increase in metformin use, which is usually prescribed under these conditions. Current data on the efficacy of metformin for the treatment of male reproductive disorders are quite controversial. Therefore, finding new targets for therapy of MS-related pathologies is one of the most important tasks of modern fundamental and applied medicine.

The study aimed to evaluate the efficacy of metformin and its combination with lipoflavone (liposomal form of quercetin) using the main criteria for gonadoprotective action under administration to male rats with MS. Male rats with an initial body weight of 50-70 g, 3 weeks of age were used in experiments. Besides, virgin pubescent females weighing 160-180 g were used to mate with males. Animals were randomized to 4 groups of 12 rats each: 1 - intact; 2 - animals, which instead of drinking water received a $10 \%$ solution of fructose for 60 days (model of MS); 3 - animals with MS that received metformin $266 \mathrm{mg} /$ $\mathrm{kg} \mathrm{b.} \mathrm{w.} \mathrm{in} 1 \%$ starch gel intragastrically during the last 30 days of fructose intake; 4 - animals with MS and co-administration of metformin in the above regimen and lipoflavone (intraperitoneally at dose of $3,1 \mathrm{mg} /$ $\mathrm{kg} \mathrm{b.} \mathrm{w.} \mathrm{(by} \mathrm{quercetin))} \mathrm{during} \mathrm{the} \mathrm{last} 30$ days of fructose intake. After 42 days from the start of the experiment, males were paired with intact females. At the end of the mating period, males were decapitated 
under mild ether anesthesia. The rate of induced by ascorbate thiobarbituric acid product formation and the content of reduced glutathione were determined in the homogenate of the testes. The level of serum ceruloplasmin was determined by the Ravin method.

The changes in the absolute mass and volume of testes of rats that consumed a high-fructose diet reflect the degenerative changes in the testicular tubules. Co-administration of metformin and lipoflavone promoted normalization of these indices to control levels. Combined administration of the investigated preparations to rats, in addition to normalizing the effect on the morphometric parameters of the gonads, also contributed to the restoration of sperm count from the caudal part of the epididymis and increase the fertility of male rats. Comparing the results of the embryonic mortality rate study in the females fertilized by the experimental males, we noted the increase in the percentage of pre- and postimplantation death, as well as the overall mortality in the group with MS compared with the control in 1,9; 3 and almost 2 times. It is noteworthy that the administration of metformin did not significantly affect the overall respectively embryonic lethality rates compared to the MS group, whereas in the animals treated with metformin and lipoflavone combination therapy the overall percentage of embryonic losses was lower than 2,3 folds.

It has been shown that the implementation into the MS treatment regimen, beside of metformin, lipoflavone contributed to the optimization of gonadoprotective action due to the restoration of the testicular microenvironment pro/antioxidant status, as evidenced by the positive modulation of the testicular antioxidant protection system components (SOD activity, reduced glutathione level) and recovery of steroidogenic activity of the testes.

The results of our study suggest that the use of only one metformin is insufficient to correct reproductive disorders caused by MS. It is advisable to use substances with a broader spectrum of therapeutic activity, such as lipoflavone (phosphatidylcholine liposome with quercetin - bioflavonoid with potent antioxidant and anti-inflammatory properties) used in our study.

Key words: metabolic syndrome metformin, lipoflavon, testes

Надійшла: 29 липня 2019 p.

Прийнята до друку: 4 вересня

Контактна особа: Шаяхметова Ганна Михайлівна, доктор біологічних наук, ду «Інститут фармакології та токсикології НАМНУ», буд. 14, вул. Антона Цедіка, м. Київ, 03057 . Тел.: + 380444567865.

Електронна пошта: anna shayakhmetova@yahoo.com 